\title{
Processes and patterns of oceanic nutrient limitation
}

\author{
C.M. Moore", M. M. Mills, K. R. Arrigo, I. Berman-Frank, L. Bopp, P. W. Boyd, E. D. Galbraith, \\ R. J. Geider, C. Guieu, S. L. Jaccard, T. D. Jickells, J. La Roche, T. M. Lenton, N. M. Mahowald, \\ E. Marañón, I. Marinov, J. K. Moore, T. Nakatsuka, A. Oschlies, M. A. Saito, T. F. Thingstad, \\ A. Tsuda and O. Ulloa
}

\begin{abstract}
Microbial activity is a fundamental component of oceanic nutrient cycles. Photosynthetic microbes, collectively termed phytoplankton, are responsible for the vast majority of primary production in marine waters. The availability of nutrients in the upper ocean frequently limits the activity and abundance of these organisms. Experimental data have revealed two broad regimes of phytoplankton nutrient limitation in the modern upper ocean. Nitrogen availability tends to limit productivity throughout much of the surface low-latitude ocean, where the supply of nutrients from the subsurface is relatively slow. In contrast, iron often limits productivity where subsurface nutrient supply is enhanced, including within the main oceanic upwelling regions of the Southern Ocean and the eastern equatorial Pacific. Phosphorus, vitamins and micronutrients other than iron may also (co-)limit marine phytoplankton. The spatial patterns and importance of co-limitation, however, remain unclear. Variability in the stoichiometries of nutrient supply and biological demand are key determinants of oceanic nutrient limitation. Deciphering the mechanisms that underpin this variability, and the consequences for marine microbes, will be a challenge. But such knowledge will be crucial for accurately predicting the consequences of ongoing anthropogenic perturbations to oceanic nutrient biogeochemistry.
\end{abstract}

T he biomass of all living organisms consists of around 30 of the 92 naturally occurring elements (Fig. 1a and Supplementary Table S1) $)^{1,2}$. All organisms must obtain chemical forms of these essential elements, termed nutrients, from their external environment. The key role that nutrients play in controlling upper-ocean productivity has long been recognized ${ }^{3-5}$. Research over recent decades, however, has yielded important new insights into nutrient biogeochemistry, including the importance of numerous trace metals ${ }^{6}$, co-limitation by two or more nutrients ${ }^{7,8}$, and variability in nutrient requirements related to microbial function, environment and evolution $^{2,7,9-11}$. Here, we present an overview of these recent advances, with reference to key concepts of nutrient limitation, and new data syntheses. Anthropogenic forcing will increasingly influence oceanic nutrient cycling ${ }^{12,13}$. We consider the potential impact of such environmental changes on nutrient limitation, ocean biogeochemistry and the carbon cycle ${ }^{14}$.

\section{Concepts of nutrient limitation}

Nutrient elements constitute one of three principal resources required for life, alongside space to live, and energy in the form of chemical reducing equivalents and high-energy bonds. Organisms that use light to fix carbon dioxide, termed photoautotrophs, are responsible for the vast majority of primary production, both on land and in the ocean. Consequently, sunlight is the ultimate source of energy for most of the biosphere ${ }^{15}$. Energy imposes an important constraint on primary productivity in the open ocean. The rapid attenuation of light with depth restricts the growth of the oceanic photoautotrophic microbes, collectively termed phytoplankton, to a thin euphotic layer (Fig. 2a). Phytoplankton and other microbes take up nutrients from this near-surface layer and assimilate them into macromolecules, resulting in the formation of particulate organic matter. Downward transport of organic material ${ }^{16}$, combined with microbially mediated remineralization, enhances nutrient concentrations below the euphotic zone (Fig. 2a), whereas the biological uptake of nutrients in the surface can result in depletion to levels that restrict microbial processes ${ }^{5}$ (Fig. 2a). Consequently, biological activity influences the cycling of nutrients throughout the ocean.

The term nutrient limitation (Box 1) encompasses a hierarchy of different scales of biological and ecological complexity, from the single cell to the biosphere (Fig. 2b). At the cellular scale, external nutrient concentrations can be so low that rates of nutrient transport to the cell surface, and thus the cellular interior, restrict the internal nutrient pool (quota) and consequently the growth rate of the cell (Box 1) $)^{17,18}$. The depletion of external nutrient concentrations typically results from integrated nutrient assimilation by the whole microbial community. The availability of nutrients may thus also set a limit on the overall community biomass yield (Box 1) $)^{18,19}$. Within the diverse microbial communities that characterize oceanic systems, the degree of growth rate limitation may vary between populations ${ }^{20-22}$, for example because of differences in cell size $e^{23,24}$ and cellular element requirements ${ }^{8,25}$ (Box 2).

Although the growth rate of individual cells may depend on nutrient availability, the net growth rate of cell populations is also profoundly influenced by predation and other loss processes ${ }^{5}$. Ecological interactions can thus influence nutrient limitation by modifying species composition and abundance at multiple scales (Fig. 2b). For example, the enhanced supply of a limiting nutrient may provide little immediate benefit for the organisms that initially dominate the community, as these may be highly adapted to the lack of this resource in the environment and/or under tight grazer control $^{22-24}$. Addition of any limiting nutrient could, however, still increase community biomass, for instance by enhancing the growth 


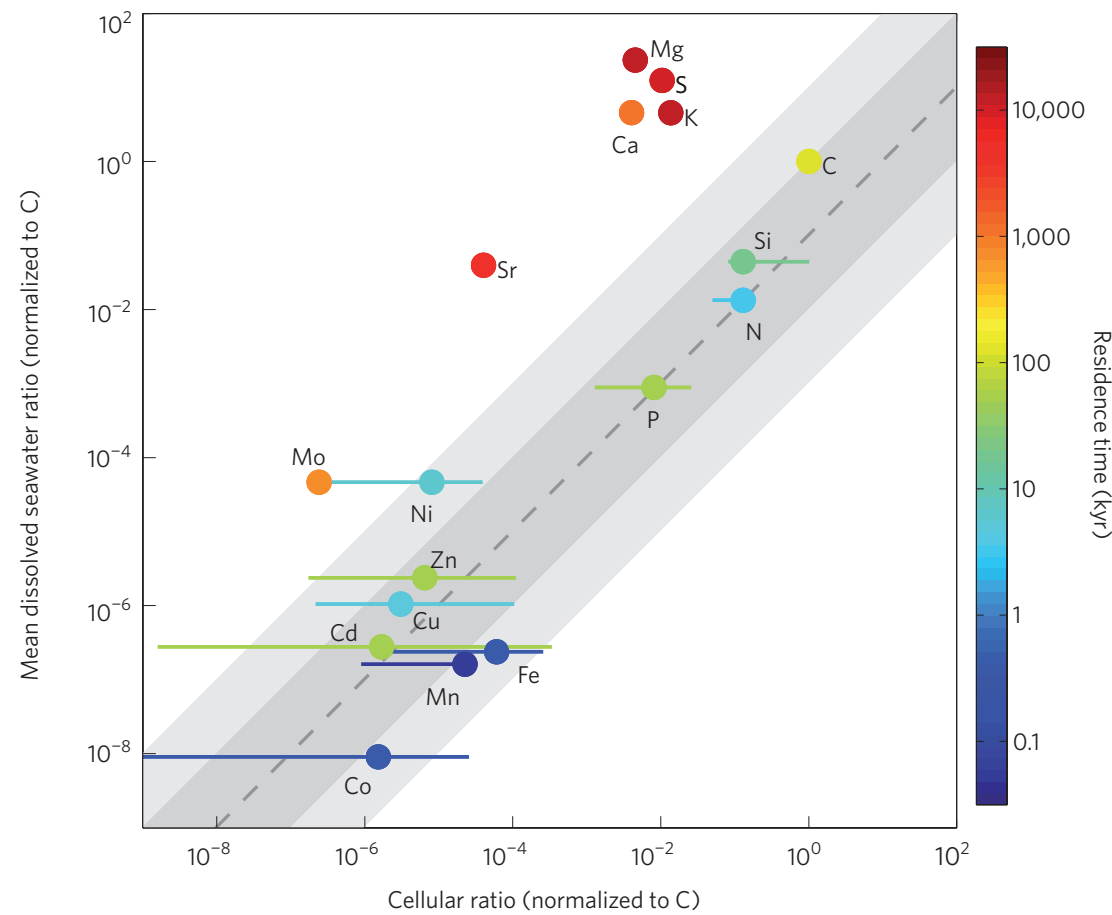

b

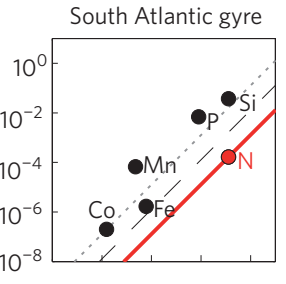

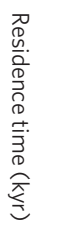

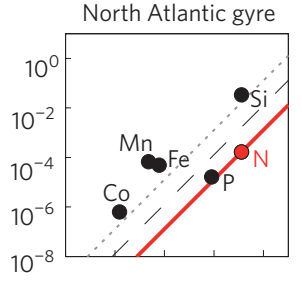

d

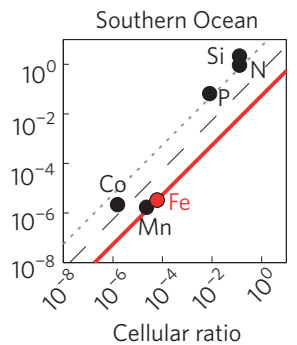

Figure 1 | Comparisons between intracellular and dissolved seawater elemental stoichiometry. $\mathbf{a}$, Representative (circle) and observed range (bar) of elemental ratios in oceanic phytoplankton normalized to carbon (nutrient:C quotas), plotted against mean dissolved seawater ratios. Colours indicate oceanic residence times (see Supplementary Table S1 for data and full list of references). Dark and light grey regions indicate $<10$-fold and $<100$-fold excesses and deficiencies relative to nitrogen, which is limiting over much of the ocean (Fig. 3). Elements to the top left of the shaded area are thus in great excess in sea water, and biological processing has little influence on their distribution, whereas some of those in the shaded regions have the potential to become limiting. b-d, Intracellular quotas versus surface dissolved seawater concentrations (normalized to mean ocean nitrate) for three oceanic regions. For clarity, intracellular stoichiometric variability is neglected and only the macronutrients N, P, Si and the scavenged micronutrients, Co, Mn, Fe are indicated (for additional detail and references see Supplementary Fig. S2). Experimental addition of the nutrient indicated in red typically promotes the most immediate (proximal) biological response in each region (Fig. 3), with solid red, dashed and dotted diagonal lines delineating elements that are as deficient as this nutrient, and 10 - and 100 -fold more replete than this nutrient, respectively.

rates of initially rare larger phytoplankton that are more resistant to grazing ${ }^{18,22}$. Such mechanisms are supported by the observation that mean cell size in a community generally increases in parallel with overall community biomass ${ }^{26}$.

Interactions between multiple nutrients also strongly influence microbial dynamics. A range of different nutrients can potentially co-limit microbial processes in the ocean (Box 1) $)^{7,8}$. Moreover, the nutrients that exert direct (or proximal) control over a microbial cell or community may differ from those that set the ultimate constraint on system productivity ${ }^{18,27}$. A conceptual two-nutrient, two-organism model represents a well-studied case ${ }^{4,27}$. The ability to convert dinitrogen gas into the other forms of nitrogen that are more readily available, collectively termed fixed nitrogen, is restricted to groups of microbes termed diazotrophs. Loss of fixed nitrogen through the microbial processes of denitrification and/or anammox thus creates a niche for diazotrophs, through effectively generating an excess of other nutrients (that is, phosphorus). As a consequence, at least conceptually, levels of fixed nitrogen can proximally limit non-diazotrophic phytoplankton, whereas the phosphorus inventory sets an ultimate constraint on the nitrogen inventory ${ }^{27}$. In the ocean other factors may complicate this simple scenario, including restrictions on diazotrophy when iron availability is low ${ }^{28-31}$.

Establishing the identity of a single ultimate limiting nutrient may thus be less relevant than understanding the controls on, and feedbacks pertaining to, any given process (Fig. 2b). For example, within the modern ocean there is no single nutrient for which the surface concentration, or overall inventory (see Supplementary
Information), could be considered limiting in isolation. Given the range of usage, discussions of nutrient limitation should specify the process being considered ${ }^{18}$, alongside the scales relevant to that process, to prevent conceptual misunderstandings.

\section{Central role of stoichiometry in microbe-nutrient interactions} Quantitative relationships between chemicals within both intracellular and extracellular nutrient pools (referred to as stoichiometry) are key determinants of oceanic biogeochemical cycles ${ }^{1-4}$. Six of the essential elements (C, H, N, O, P and S) constitute over 95\% of organic matter by mass, principally in the form of the macromolecules: carbohydrates, proteins, nucleic acids and lipids ${ }^{2,9}$. Furthermore, all organisms require inorganic ions (for example calcium, potassium and sodium) and a range of trace elements, including iron, manganese, cobalt, zinc and copper (Fig. 1a). The latter are found within a diverse array of metal-containing enzymes ${ }^{6,8,32}$. Mineral phases, such as silicon dioxide and calcium carbonate, are also essential for some organisms.

Alfred Redfield first drew attention to the co-variability of dissolved nitrate and phosphate in the ocean interior, and the similarity of this ratio to N:P ratios within particulate organic matter and cellular material ${ }^{3}$. Oceanographers have since employed the 'Redfield ratio' of 106C:16N:1P as a key stoichiometric concept in ocean biogeochemistry ${ }^{33,34}$. Cellular ratios have also been extended to include other elements ${ }^{35}$. It has long been recognized, however, that there is considerable variability in the stoichiometric ratios for all the elements within cellular material ${ }^{2,9,36-38}$ (Fig. 1a). 
a

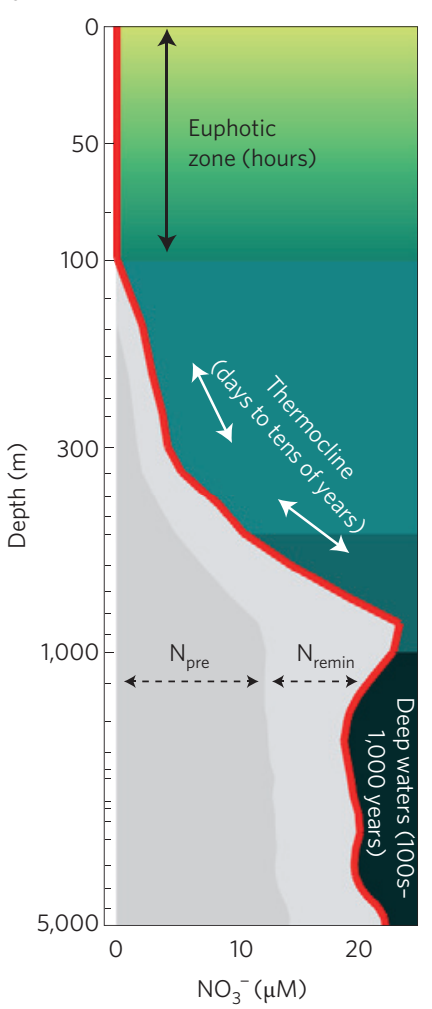

b

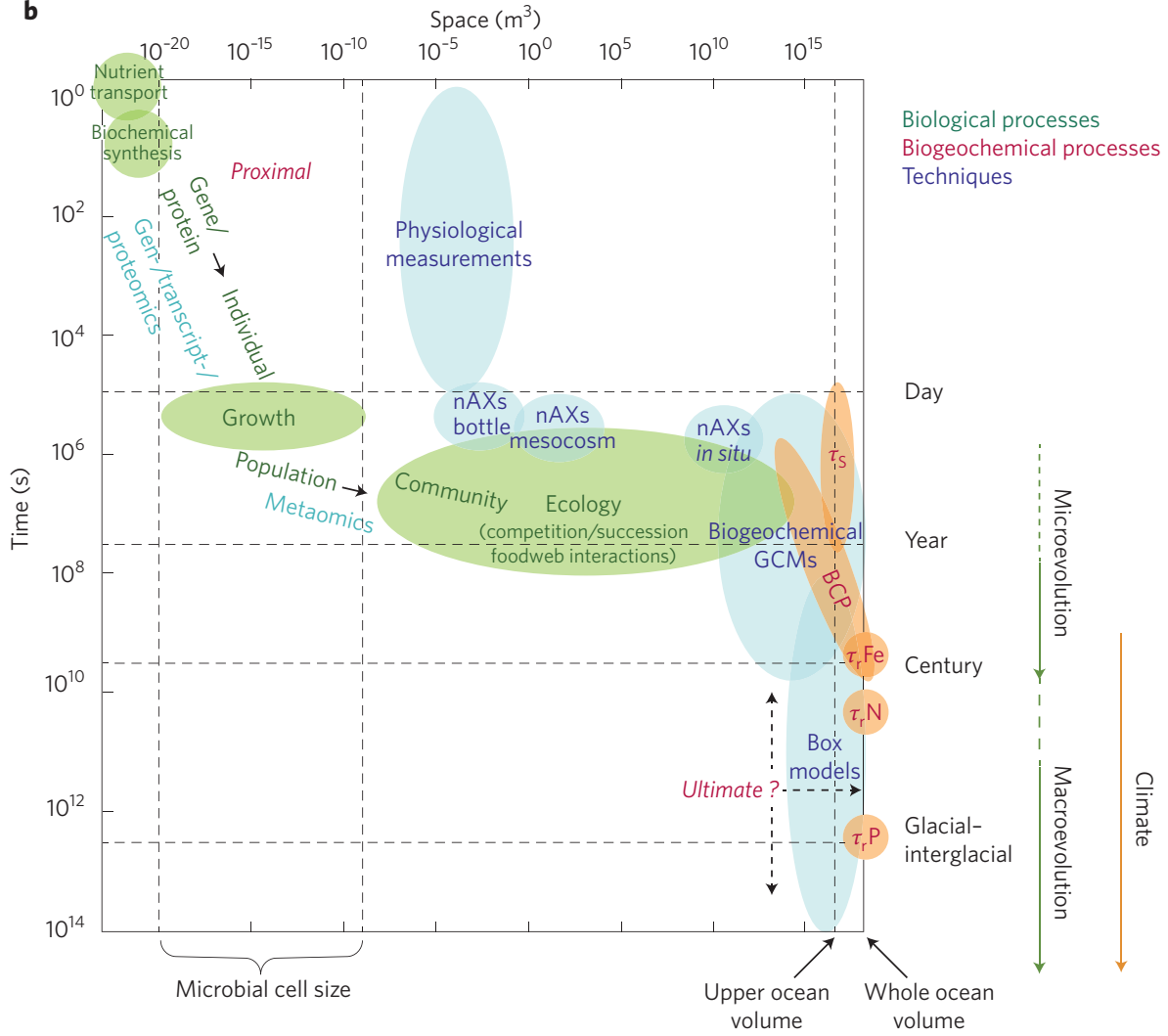

Figure $\mathbf{2}$ | Example timescales and space scales of nutrient-related phenomena. a, Profile of the principal bioavailable form of nitrogen (nitrate) in the subtropical North Atlantic Ocean (note logarithmic depth scale). Near-complete depletion of nitrate occurs in the euphotic zone, whereas concentrations are enriched at depth owing to both the remineralization of particulate organic matter $\left(\mathrm{N}_{\text {remin }}\right)$ and physical transport of waters containing nitrate that was unutilized before these waters sank $\left(\mathrm{N}_{\text {pre }}\right)$. Representative timescales for mixing back to the surface are indicated. $\mathbf{b}$, Schematic illustration of the timescales and space scales of processes, levels of biological-biogeochemical organization and observational techniques related to oceanic nutrient cycling. Interactions and feedbacks occur over all scales. For example, large-scale biogeochemistry is influenced by the integrated activity of the microbes operating at much smaller times and space scales. GCM, general circulation model; nAXs, nutrient addition experiment; BCP, biological carbon pump; $\tau_{\mathrm{s},}$ turnover times of nutrients in the surface layer; $\tau_{\mathrm{r}} \mathrm{Fe}, \mathrm{N}, \mathrm{P}$, whole-ocean residence times of the key nutrients iron, nitrogen and phosphorus.

Variability in ocean geochemistry throughout evolutionary history has resulted in significant stoichiometric differences among taxa. In particular, changes in the relative availabilities of trace metals during redox transitions in ancient oceans have left imprints on the metal-binding proteomes, and hence trace-metal requirements, of modern organisms ${ }^{1,10,32,39}$. Ratios of C:N:P also vary between taxa, potentially reflecting ecological trade-offs in the allocation of carbon (and associated nutrients) amongst macromolecules associated with different functions ${ }^{9-11,35}$. The availability of nutrients in the environment also drives extensive phenotypic differences in cellular composition ${ }^{2,9,36-38}$. Other processes, including acclimation to light intensity, can also significantly influence cellular elemental composition $^{11,37}$. As cells acclimate to environmental variability, plasticity in intracellular elemental stoichiometry broadly reflects the changing ratios of functional macromolecular pools (for example proteins and ribosomes), alongside the accumulation or depletion of energy (carbohydrates and neutral lipids) or nutrient reserves (such as polyphosphate, nitrate and ferritin) ${ }^{2,9,11}$. Substitutions between different metal-containing enzymes, or the metals bound by the enzymes, can also contribute to stoichiometric flexibility for these micronutrient elements $\mathrm{s}^{2,6,8,9,36}$.

The degree of variability in cellular elemental quotas seems to decline with increasing cellular requirements (Fig. 1a and Supplementary Fig. S1). Elements incorporated within larger biochemical pools will probably be involved in a wider range of metabolic processes. For example, nitrogen represents over $7 \%$ of cellular mass in marine microbes, being a major constituent of both proteins and nucleic acids'. Although there is scope for substitution and/or maintenance of metabolism at reduced cellular nitrogen concentrations $s^{40}$, this seems relatively restricted. In contrast, phosphorus requirements, which typically account for around $1 \%$ of microbial mass, can be more significantly reduced under limiting conditions. For example, a substantial proportion of one of the major cellular pools, the phospholipids, can be substituted for nonphosphorus-containing lipids $\mathrm{s}^{25}$. The cellular $\mathrm{C}: \mathrm{N}$ ratio thus seems more constrained than the C:P (and hence $\mathrm{N}: \mathrm{P}$ ) ratio ${ }^{9,10}$. Plasticity is even higher for many of the trace metals (Fig. 1a), as excess intracellular accumulation can occur when external availability is high, and substitutions can occur under limiting conditions $\mathrm{s}^{6,8,36}$.

Cellular stoichiometry and associated uptake ratios dictate how surface organic matter production both responds to and influences the differential availability of nutrients ${ }^{2,4,7,41-44}$. Assuming no other constraints operate, strict conservation of cellular stoichiometry would dictate that the nutrient in most deficient supply to the surface layer should limit the rate of new biomass production (Box 1). Supply from the subsurface will dominate for many nutrients (Fig. 2a). But additional inputs, for example from the atmosphere, may also be significant for some nutrients, influencing patterns of limitation ${ }^{45,46}$. Moreover, stoichiometric plasticity (Fig. 1a) and variable surface recycling rates for different elements ${ }^{41}$ may further decouple the proximally limiting nutrient from what might be predicted on the basis of dissolved nutrient stoichiometry within 
a

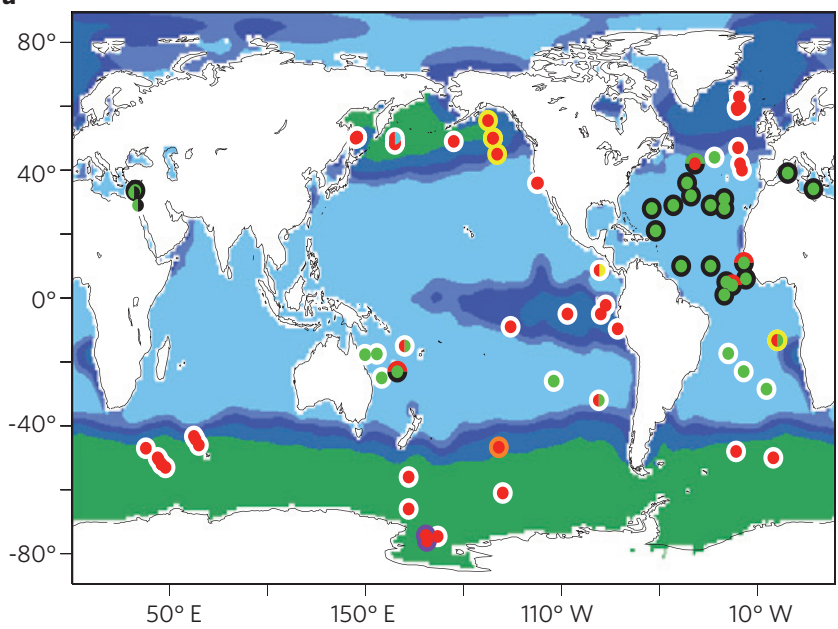

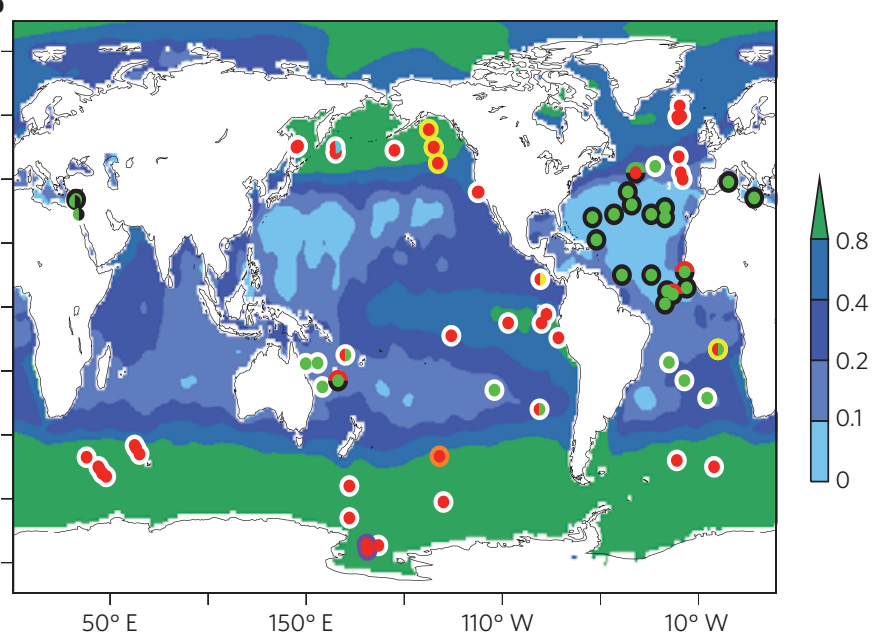

Figure 3 | Patterns of nutrient limitation. Backgrounds indicate annual average surface concentrations of nitrate (a) and phosphate (b) in $\mu \mathrm{mol} \mathrm{kg}^{-1}$. To assist comparison, nitrate is scaled by the mean N:P ratio of organic matter (that is, divided by 16; Fig. 1) ${ }^{34}$. Symbols indicate the primary (central circles) and secondary (outer circles) limiting nutrients as inferred from chlorophyll and/or primary productivity increases following artificial amendment of: $\mathrm{N}$ (green), P (black), Fe (red), Si (orange), Co (yellow), Zn (cyan) and vitamin B12 (purple). Divided circles indicate potentially co-limiting elements. White outer circles indicate that no secondary limiting nutrient was identified, which in many cases will be because of the lack of a test. See Supplementary Table S2 for references.

local subsurface pools (Supplementary Fig. S2) 41,47,48 $^{\text {. A significant }}$ proportion of the subsurface pools of many nutrients results from remineralization of organic matter produced in the surface layer (Fig. 2a and Supplementary Table S1). Consequently, the elemental composition of organic matter production (Fig. 1a), alongside any variability in remineralization rates between elements ${ }^{33,41}$, can also influence subsurface nutrient stoichiometry $y^{4,41-44}$.

Stoichiometry thus exerts a fundamental control on nutrient limitation and the coupling between the biogeochemical cycles of the different nutrients $s^{2,4,44,49}$. Most present-day large-scale ocean biogeochemical models tend to assume fixed stoichiometries for many elements $^{45,50,51}$ (see Supplementary Information). Although implementation of more realistic physiological parameterizations will be challenging ${ }^{50}$, it may be necessary for improved representation of current nutrient limitation patterns in these models ${ }^{45,46}$.

\section{Patterns of phytoplankton nutrient limitation}

Over much of the surface ocean, non-nutrient constraints on net community growth, such as light levels, grazing and viral infection, seem insufficient to prevent the depletion of at least one nutrient to concentrations where experimental amendment can, at times, elicit a rapid biological response (Fig. 3). Large-scale spatial patterns of limiting nutrients have been inferred from multiple lines of evidence. Absolute concentrations of surface nutrients, or their stoichiometric ratios, provide an indication of the potential for limitation or deficiency (Box 1), respectively. Surface inorganic nitrogen and phosphorus concentrations are highly depleted throughout much of the low-latitude oceans (Figs 1b,c and 3). Phosphorus is typically in excess of nitrogen relative to cellular requirements ${ }^{34}$ (Figs 1 and 3). But this is not the case everywhere; both of the Northern Hemisphere oligotrophic gyres have lower surface phosphate concentrations than the southern gyres (Figs $1 b, c$ and $3 b$ and Supplementary Fig. S2) ${ }^{31,41,52}$. Surface depletion of micronutrients, such as $\mathrm{Fe}, \mathrm{Co}, \mathrm{Zn}, \mathrm{Cu}, \mathrm{Ni}$ and $\mathrm{Cd}$, is also observed in many regions ${ }^{6}$. Perhaps the classic example of how analytical advances can transform our understanding of oceanic nutrient cycles ${ }^{5}$ concerns the socalled high-nitrate low-chlorophyll regions. The long-hypothesized deficiency of iron in these environments was only confirmed following improved sampling and measurement techniques ${ }^{5,53,54}$ (Fig. 1d).
Variable cellular stoichiometry (Fig. 1a), the rapid turnover of nutrients within the foodweb ${ }^{5,20}$, and the differing capacity of microbial groups to access different nutrient species (termed bioavailability ${ }^{6}$; see Supplementary Information) complicate inferences of limitation or deficiency based on observed concentrations (Fig. 1b-d). Consequently, experimental approaches to directly assess nutrient limitation of marine microbes have been used for at least 50 years $^{55}$. Nutrient manipulation experiments have included additions of specific nutrients to natural microbial communities enclosed in bottles ${ }^{53}$ and in situ enrichments in the open ocean ${ }^{20,54}$. A compilation of such experimental data for phytoplankton reveals coherent large-scale patterns, and a clear relationship between proximal nutrient limitation and the concentrations of nutrients (Figs $1 b-d$ and 3 ). These patterns seem robust to differences in methods, including variable timescales and space scales (Fig. 2b), and to the wide range of ecophysiological and molecular techniques used to monitor responses.

In the low-biomass (oligotrophic) waters that dominate the lowlatitude oceans, phytoplankton biomass and productivity typically only increase following experimental addition of nitrogen ${ }^{47,52,56}$. In contrast, in high-nitrate low-chlorophyll waters (Fig. 3), increases in phytoplankton biomass and productivity often result from the addition of iron alone, in both bottle and in situ experiments ${ }^{53,54}$. In certain oligotrophic regions, including the eastern Mediterranean ${ }^{20,48}$ and the subtropical North Atlantic ${ }^{25,41,57,58}$, bioavailable forms of phosphorus can become severely depleted alongside nitrogen (Figs 1c and 3), and microbial populations frequently show evidence of phosphorus stress (Box 1) ${ }^{20,25,57,58}$. Even in these systems, however, addition of phosphorus alone does not typically result in increased autotrophic activity or biomass ${ }^{20,47,48,59}$. Rather, once stratified oligotrophic conditions are well established, N limitation or NP co-limitation seems to occurr ${ }^{47,48,59}$. The higher bioavailability of organic phosphorus compounds ${ }^{41,48}$ (see Supplementary Information), acclimatization mechanisms for coping with phosphorus stress ${ }^{25}$ and/or the selection for higher N:P stoichiometry under low nutrient conditions ${ }^{11}$ could explain the tendency towards nitrogen limitation.

Other nutrients can be almost as deficient as nitrogen, iron and phosphorus (Fig. 1 b-d and Supplementary Fig. S2). But our 


\section{Box 1 | Concepts of nutrient limitation}

Nutrient scarcity may restrict a number of biological and ecological processes ${ }^{18}$. Thus, it is necessary to identify the specific process being 'limited', and it is worth considering the different conceptual frameworks and terms that have been used in discussing nutrient limitation ${ }^{5,7,8,17-19}$

Blackman and Liebig. Low nutrient concentrations can limit the growth rate of individual cells, and the total available amount of a nutrient can also set an upper bound on the amount of new biomass that can be formed (the yield) ${ }^{5,18}$. These concepts are often referred to as Blackman and Liebig limitations ${ }^{5,18}$, respectively, after two pioneers working on different aspects of plant production. F. F. Blackman ${ }^{17}$ studied photosynthesis in leaves whereas J. von Liebig ${ }^{19}$ worked on agricultural crop yields. The yield perspective could be extended to consider the total biomass that can be formed at all trophic levels, including heterotrophic microbes, zooplankton and viruses.

Stress and deficiency. The distinct concepts of stress and deficiency are also sometimes referred to as nutrient limitation. Although usage varies, we define stress as a physiological response to a nutrient shortage and deficiency as the stoichiometric lack of one element relative to another. For example, assuming a fixed biological $\mathrm{N}: \mathrm{P}$ stoichiometry of $16: 1$, if the concentration or flux of dissolved $\mathrm{N}$ falls below 16 times $\mathrm{P}$, a system could be considered nitrogendeficient. Stress and deficiency are more closely related to, but

understanding of the importance and geographic extent of multinutrient interactions (beyond those of nitrogen and phosphorus $)^{47,48,59}$ is less complete, owing to a scarcity of experiments and the potential limitations of current methodologies ${ }^{8}$. Experiments that use a factorial matrix of differing nutrients provide evidence of secondary and/or co-limitation in both high-nitrate low-chlorophyll and oligotrophic environments (Fig. 3 and Supplementary Table S2). Such approaches are logistically challenging, however, and may not be capable of detecting a range of known metalmetal interactions, including the biochemical substitution of one metal for another ${ }^{8}$ (Box 1).

Molecular diagnostics, including the expression of specific genes or the presence of biomarker proteins, hold promise for the future assessment of multiple nutrient interactions for phytoplankton ${ }^{60}$ and other microbial groups. A variety of techniques could potentially be used to determine simultaneous multiple nutrient stress on individual phytoplankton taxa, circumventing logistical problems and caveats associated with bottle incubations. Individual diagnostics of both iron and phosphorus stress have already been used ${ }^{57,61}$, and emerging technologies will aid in more in-depth sampling of nutrient-related gene expression ${ }^{62}$ and protein abundance profiles.

Overall, our synthesis of experimental data (Fig. 3) supports prior model predictions $s^{45,46}$ and can be used to infer that there are two broad nutrient limitation regimes in the modern ocean. About $30 \%$ of the ocean's surface area consists of high-macronutrient, iron-limited systems, with most of the remaining low-latitude oligotrophic systems being nitrogen-limited (or in places co-limited by nitrogen and phosphorus) (Fig. 3). Certain phytoplankton groups may have additional specific requirements. For example, silicon availability may limit diatoms $\mathrm{s}^{21,45}$. Emerging evidence also points to the potential for other micronutrients and vitamins, such as Co, $\mathrm{Zn}$, $\mathrm{Ni}$ and vitamin $\mathrm{B}_{12}$, to have secondary or subtle interactive influences beyond the primary $\mathrm{N}(\mathrm{P})$ or Fe limitations in some regions ${ }^{7,8}$. Variability in the stoichiometry of phytoplankton cellular elemental quotas (Fig. 1) $)^{11,25}$ and upper-ocean nutrient cycling ${ }^{41,48}$, as well clearly not synonymous with, the concepts of Blackman and Liebig respectively. There need not be a consistent relationship between the degree of physiological stress and growth rate ${ }^{99}$, and the most deficient nutrient will not become limiting if all remain replete.

Nutrient co-limitation. Conditions where two or more nutrients are co-limiting may be common in oceanic systems, but usage of the term varies greatly ${ }^{7,8}$. Nutrient co-limitation is typically ascribed to conditions where two (or more) nutrients have simultaneously been drawn down to levels where addition of both (or on some usage either) is required to stimulate growth. This may happen in a number of ways ${ }^{7,8}$. First, two or more nutrients can simply be drawn down to equally limiting levels so that both must be added to observe a growth response. Second, one limiting nutrient may be biologically substituted with another ${ }^{36}$, either directly within the same macromolecule or indirectly by substituting one macromolecule for another. Third, the ability to take up low concentrations of one nutrient may depend on the availability of another nutrient ${ }^{8}$. Finally, one member of the microbial community may respond to the addition of one nutrient whereas another member responds to that of a different nutrient ${ }^{7}$. In the last three scenarios, addition of either nutrient elicits a growth response. Within nutrient addition experiments it may be difficult to distinguish the various types of co-limitation from each other, or from a secondary response due to addition of a nutrient depleted to levels where it is close to co-limiting ${ }^{8,47}$.

as physical mixing between water masses with contrasting nutrient stoichiometry (Fig. 3), may provide mechanisms for generating regions of co-limitation. The seasonal cycle can also influence patterns of (co-)limitation ${ }^{21,48}$, as physical nutrient inputs and other drivers, including light levels, combine with biological cycling to alter nutrient availability.

\section{Potential for change}

Significant changes in nutrient biogeochemistry have occurred over glacial-interglacial cycles (see Supplementary Information), indicating the potential for altered patterns of upper-ocean nutrient limitation ${ }^{63-65}$. A range of processes could influence nutrient availability in the future, including altered nutrient demands, increasing external nutrient inputs and changes in surface ocean chemistry driven by anthropogenic increases in atmospheric carbon dioxide concentrations. Changes in ocean circulation could also play a key role, owing to the dominance of physical supply from depth (Fig. 2a) on the fluxes of many nutrients to the euphotic zone ${ }^{16}$. At the global scale, physical resupply is dominated by the Southern Ocean, where strong upwelling brings macronutrient-rich deep waters to the surface $^{43}$. These waters are deficient in those trace metals that have short oceanic residence times due to scavenging losses (Fig. 1a,d) ${ }^{6,66}$, contributing to the tendency for iron limitation in the Southern Ocean (Fig. 3). A proportion of the surface macronutrients that remain unused in the Southern Ocean (Fig. 1d) is subsequently transported northwards within the thermocline, where smaller-scale upwelling and mixing eventually supports production in the largely nitrogenlimited (Fig. 3) low latitudes ${ }^{43}$.

Anthropogenic carbon dioxide emissions and increasing temperatures. Continued anthropogenic carbon dioxide emissions and resulting ocean warming may influence oceanic nutrient cycles. Oceanic uptake of anthropogenic carbon dioxide directly alters ocean chemistry by changing inorganic carbon speciation, lowering $\mathrm{pH}$ and potentially affecting the speciation of some nutrients. For 


\section{Box 2 | Competition in low-nutrient environments}

Under stable low-nutrient concentrations, the specific affinity ( $\alpha$, $\mathrm{m}^{3} \mathrm{~mol}^{-1} \mathrm{~s}^{-1}$ ), the slope of the relationship between growth rate and bulk concentration of a nutrient, represents a key parameter describing the competitive ability of microorganisms ${ }^{100}$. Assuming that diffusive transport towards a (for simplicity, spherical) cell becomes rate-limiting when the bulk concentration of the nutrient drops below some critical level, mechanisms for achieving a high $\alpha$, and hence competitive advantage, can be understood by considering two readily derived expressions (Supplementary Information):

$$
\begin{gathered}
\alpha=4 \pi D r / Q \\
\text { or } \\
\alpha=3 D / \sigma r^{2}
\end{gathered}
$$

where $D$ is the diffusion constant for the nutrient $\left(\mathrm{m}^{2} \mathrm{~s}^{-1}\right), r$ is the cell radius $(\mathrm{m}), Q$ is the cell nutrient quota $(\mathrm{mol})$ and $\sigma$ is the average whole-cell concentration of the nutrient $\left(\mathrm{mol} \mathrm{m}^{-3}\right)$, that is, $3 Q / 4 \pi r^{3}$ for a spherical cell.

At constant $\sigma$, small cells with high surface area to volume ratios will have a competitive advantage (equation (1b)). This size dependence of nutrient competition has probably been a key driver of phytoplankton (and more generally osmotroph) evolution, explaining the dominance of picophytoplankton in very low-nutrient oligotrophic systems ${ }^{23,24}$. In contrast, if constant $Q$ can be maintained, increased size may actually represent an advantage (equation (1a)), a strategy that vacuolated organisms such as diatoms may adopt ${ }^{100}$. Finally, for a given size, minimization of $Q$ or $\sigma$ (equation (1a) or (1b)) will maximize competitive ability, formalizing the advantage gained from cellular substitutions of limiting nutrient ${ }^{8,25}$ and other adaptive traits, including, for example, minimization of protein nitrogen costs in oligotrophic waters ${ }^{40}$.

example, the bioavailability of iron ${ }^{67}$ or the biological oxidation rate of ammonia ${ }^{68}$, a fixed $\mathrm{N}$ species, might decrease. Any co-occurring changes in nutrient supply and demand must, however, be taken into account when attempting to predict overall consequences for upper ocean nutrient limitation ${ }^{68,69}$.

The climate impacts of increased atmospheric carbon dioxide concentrations are expected to include a strengthening in the density stratification of the upper ocean in response to warming and intensification of the hydrological cycle $^{70}$. Resulting changes in ocean circulation could influence nutrient cycling in several ways. Increased stratification may restrict the physical resupply of nutrients to surface waters ${ }^{70,71}$, with some models predicting declines in global export of particulate organic matter of around $10 \%$ by the end of the century as a consequence ${ }^{51}$. Stratification increases would be likely to involve expansion of the nitrogen-limited subtropical gyres $^{71}$ (Fig. 3). Although some observational data already support such a trend ${ }^{72}$, regional in situ records can differ $^{73}$ and longer timeseries are needed ${ }^{74}$.

Increased stratification and warming may also decrease deepwater oxygen concentrations ${ }^{75}$. Subsequent expansion of oxygen minimum zones could decrease the ocean inventory of fixed nitrogen species by increasing microbial denitrification and/or anaerobic ammonium oxidation. Expansion of oxygen minimum zones could also increase trace metal ${ }^{66}$ and phosphorus inventories by increasing the release of these nutrients from sediments, as may have occurred over glacial-interglacial cycles (see Supplementary Information). Such changes at depth could influence surface waters on timescales of decades or longer (Fig. 2a), being most significant in regions extending out from existing oxygen minimum zones in the eastern tropical Atlantic ${ }^{66}$ and Pacific and northern Indian Oceans ${ }^{75}$.

Changes in external nutrient supply. Anthropogenic activities have significantly influenced the biogeochemical cycles of many elements ${ }^{14}$. Terrestrial nutrients primarily reach the ocean through atmospheric and fluvial fluxes. These fluxes are of comparable magnitude (Table 1) but differ in their geographical distribution. Anthropogenic perturbations to both supply routes have increased the external supply of nutrient elements to the ocean (Table 1$)^{12,76-}$ 79. Anthropogenic fixed nitrogen sources are comparable to that derived from biospheric nitrogen fixation ${ }^{12,49}$, leading to increased fluvial fluxes of nitrogen to the ocean ${ }^{49}$. Riverine phosphorus fluxes have also increased by $50-300 \%$ over preindustrial levels and are expected to track future global population increases, unless declining mineral phosphorus reserves offset such changes ${ }^{80}$. Fluvial dissolved iron inputs are at present small relative to atmospheric inputs ${ }^{81}$. Any change in the estuarine trapping efficiency of the much larger fluvial particulate iron fluxes could, however, have a significant but uncertain impact on the supply of terrestrial iron to the open ocean ${ }^{82}$.

Atmospheric deposition of bioavailable fixed nitrogen to the open ocean has tripled since 1860 (Table 1), and a further 10-20\% increase is expected by $2050^{12}$. At present, most of this anthropogenic nitrogen is deposited in low-latitude nitrogen-limited regions (Fig. 3), with further increases predicted particularly to the Indian Ocean, the tropical Pacific and the waters off southern Africa ${ }^{12,13}$. The total atmospheric flux of iron into the ocean is dominated by soil dust from desert regions, resulting in strong regional gradients in deposition ${ }^{82}$, with high fluxes in the North Atlantic and western North Pacific from the Saharan and Asian deserts, and very low fluxes to the iron-limited Southern Ocean (Fig. 3). Although there is evidence that atmospheric dust has increased over the past century ${ }^{78}$, the magnitude and even the sign of further changes, resulting from continued shifts in climate and altered land use in important source regions, are difficult to predict ${ }^{78}$. Depending on the regional distribution of changes to dust and other anthropogenic inputs of iron (see Supplementary Information), biological responses might principally be expected in iron-limited regions (Fig. 3) ) $^{13,46}$ and/or in low-latitude waters where iron potentially limits diazotrophy ${ }^{29,31,83}$. Atmospheric deposition of phosphorus to the ocean predominantly comes from natural sources, and changes will be likely to parallel those of dust ${ }^{77}$. Experimental evidence has indicated the potential for a range of microbial responses to future changes in dust inputs (Supplementary Fig. S3). Overall, atmospheric fluxes are predicted to become increasingly enriched in nitrogen relative to both iron and phosphorus (Table 1).

Although the magnitude of likely changes in external nutrient inputs suggests only modest changes to whole ocean inventories on decadal timescales (Table 1) 12,13,46,78, the increased anthropogenic fluxes are still significant, particularly at local scales or when compared to natural inputs. For example, the enhanced fluvial nutrient inputs entering the coastal zone are responsible for significant eutrophication, contributing to the growth of low-oxygen waters in many regions ${ }^{84}$. Overall, anthropogenic inputs are predicted to continue increasing beyond the magnitude of natural external sources (Table 1) $)^{12,76-79}$, representing a significant biogeochemical perturbation of the whole oceanic system. For example, in addition to the well-discussed fixed nitrogen inputs ${ }^{12,46}$, the short residence time for iron (Fig. 1a) means that any future changes ${ }^{78}$ could have significant impacts over decadal to century timescales ${ }^{13,46}$ (Table 1).

Altered nutrient demand. A range of other factors alongside nutrient availability_including temperature, light, inorganic carbon availability and grazing-interact to control the physiology, growth and abundance of different marine microbial groups ${ }^{5,21,85-87}$. 


\begin{tabular}{|c|c|c|c|c|c|c|c|}
\hline & \multirow[t]{2}{*}{ Date } & \multirow[t]{2}{*}{ Fluvial } & \multirow[t]{2}{*}{ Atmospheric } & \multirow[t]{2}{*}{ Glacial } & \multicolumn{3}{|c|}{ Totals as percentage of annual ${ }^{a}$} \\
\hline & & & & & $\begin{array}{l}\text { Primary } \\
\text { production (\%) }\end{array}$ & $\begin{array}{l}\text { Export } \\
\text { production (\%) }\end{array}$ & $\begin{array}{l}\text { Total } \\
\text { inventory (\%) }\end{array}$ \\
\hline \multirow[t]{3}{*}{ Total N } & $\sim 1860$ & $1,000^{b}$ (ref. 79) & 1,000 (ref. 12) & 11 (refs 96,97) & 0.3 & 1.5 & 0.005 \\
\hline & 2000 & $2,100^{b}$ (ref. 79) & 4,800 (ref. 12) & 11 (ref. 96) & 1.2 & 5.3 & 0.017 \\
\hline & 2050 & $2,300^{b}$ (ref. 79) & 5,500 (ref. 12) & 11 (ref. 96) & 1.3 & 5.9 & 0.019 \\
\hline \multirow{2}{*}{ Total P } & 2000 & $65^{b}($ ref. 79$)$ & $21^{c}$ & 48 (ref. 98) & 0.4 & 1.6 & 0.005 \\
\hline & 2050 & $87^{b}$ (ref. 79) & $21^{c}$ & 48 (ref. 98) & 0.4 & 1.9 & 0.006 \\
\hline \multirow[t]{3}{*}{ Dissolved Fe ${ }^{d}$} & 1860 & $2^{d}($ ref. 96) & $4.3^{c}$ & $0.02^{d}$ (ref. 81) & 2 & 10 & 0.8 \\
\hline & 2000 & $2^{d}$ (ref. 96) & $9.3^{c}$ & $0.02^{d}$ (ref. 81) & 4 & 20 & 1.5 \\
\hline & 2050 & $2^{d}$ (ref. 96) & $8.8^{c}$ & $0.02^{d}$ (ref. 81) & 4 & 20 & 1.4 \\
\hline$N: P$ & & Total inputs & \multicolumn{2}{|l|}{ Mean biological } & & & \\
\hline \multirow[t]{3}{*}{$N: P$} & 1860 & $23: 1$ & \multirow[t]{3}{*}{$16: 1$} & & & & \\
\hline & 2000 & $52: 1$ & & & & & \\
\hline & 2050 & $50: 1$ & & & & & \\
\hline
\end{tabular}

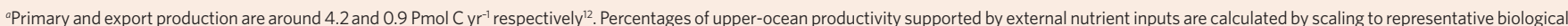
ratios (Fig.1), with estimates for iron in particular considered to be order of magnitude at best, owing to known stoichiometric plasticity (Fig. 1). Cumulative anthropogenic inputs over century timescales are thus potentially equivalent in magnitude to $100 \%, 1-2 \%$ and $<0.5 \%$ of the oceanic iron, nitrogen and phosphorus inventories, respectively.

${ }^{b}$ Dissolved only. Particulate nitrogen and phosphorus (respectively estimated to be 960 and $210 \mathrm{Gmol} \mathrm{yr}^{-1}$ in 2000) are likely to be trapped in the near-coastal zone. Total nitrogen and phosphorus analysis for 1860 is based on reanalysis of output from ref. 79 (Seitzinger, S. P., personal communication).

'See Supplementary Information.

${ }^{d}$ Owing to uncertainty over the bioavailability of particulate iron ${ }^{81,82,96}$, we primarily consider dissolved inputs. For all glacial flows we assume no change in water flows, which in reality are likely to increase with future warming. Total (reactive particulate and dissolved) inputs are much higher, but most of the fluvial particulate iron input of around $627 \mathrm{Gmol} \mathrm{yr} \mathrm{r}^{-1}$ is probably trapped on the shelf ${ }^{82}$, although much of the glacial reactive particulate Fe supply of $140 \mathrm{Gmol} \mathrm{yr}^{-1}$ may reach the ocean ${ }^{96}$. We do not attempt to estimate the magnitude of potential changes in other dissolved iron inputs to the water column ${ }^{81}$, including increases in the important sedimentary source as a result of decreasing oxygen levels ${ }^{66,75}$. Iceberg-associated fluxes are also an important contributor, particularly in the Southern Ocean ${ }^{81}$.

Changes in these non-nutrient drivers may alter microbial activity and distribution, and hence influence overall biological uptake, a crucial determinant of nutrient limitation. For example, model studies indicate that direct physiological responses to increasing temperature could potentially influence primary (although not export) production by a magnitude comparable to the influence of increased stratification ${ }^{71,88}$. Future warming and higher carbon dioxide concentrations may also influence diazotrophic growth rates $^{85,87,89}$, potentially altering nitrogen inputs and/or phosphorus and iron uptake and hence the stoichiometry of N:P:Fe cycling in low-latitude nitrogen-limited regions (Figs 1b,c and 3). In the high latitudes, increases in stratification might increase seasonal light availability for phytoplankton and hence overall productivity ${ }^{51}$. However, the extent to which macronutrient drawdown might subsequently increase in different regions (Fig. 3) will depend on the current relative importance of light or iron availability as limiting factors, potentially alongside interactions with altered iron supply and other potential drivers ${ }^{21,69}$.

Establishing the dominant environmental controls on the ecophysiology of different microbial groups in diverse regimes thus remains a crucial challenge. Biogeochemical responses are unlikely to be simply related to single environmental drivers. Mechanistic understanding of individual physiological responses and how they interact ${ }^{21,50}$ will need to guide the next generation of numerical models if these are to provide accurate predictions of how future changes in patterns of nutrient supply and biotic demand will combine to alter regional nutrient limitation (Fig. 3) (3,46 $^{\text {. Geographical }}$ shifts in the boundaries between the two broad regimes of nutrient limitation apparent at basin scales (Fig. 3) would be a likely primary consequence of changes in either external inputs ${ }^{46}$, internal transports related to oceanic circulation ${ }^{71}$ or alterations in biological processes linked to other environmental drivers ${ }^{21}$.

\section{Implications for the carbon cycle}

Ultimately, changes in oceanic nutrient cycles have the potential to influence atmospheric carbon dioxide concentrations, resulting in climate feedbacks $s^{13,14,28,63}$. Partitioning of carbon dioxide between the atmosphere and oceans is driven by interacting physical, chemical and biological processes. The downward transport of nutrients resulting from the sinking and remineralization of particulate organic material formed in the surface ocean ${ }^{16}$ (Fig. 2a) is associated with a flux of carbon, frequently termed the biological pump ${ }^{90-92}$. Physical processes also transport biologically unutilized (so-called 'preformed') nutrients into the ocean interior, leading to a decreased efficiency of the biological pump. Assuming constant stoichiometry and effective air-sea equilibration of gases in the surface ocean, the biological storage of carbon in the ocean is proportional to the total inventory of nutrients in the interior that arrived through the biological 'remineralized' pathway ${ }^{90,92}$ (see Supplementary Information). Consequently, circulation patterns strongly dictate how changes in nutrient limitation can influence atmospheric carbon dioxide concentrations ${ }^{91}$. For example, the high-nitrate lowchlorophyll Southern Ocean currently represents the largest source of preformed macronutrients to the deep ocean ${ }^{63,91}$. As such, glacialinterglacial variations in atmospheric carbon dioxide levels have been linked to altered nutrient biogeochemistry in this region ${ }^{63,64}$. Past $^{64}$ or future increases in iron inputs to high-nitrate low-chlorophyll Antarctic waters could reduce excess surface macronutrients, decreasing the preformed nutrient contribution to the deep ocean and hence lowering atmospheric carbon dioxide concentrations $s^{91,93}$. 
In contrast, altered iron inputs to the high-nitrate low-chlorophyll sub-Antarctic waters could influence (macro-)nutrient input into the thermocline ${ }^{43}$, affecting phytoplankton productivity in low-latitude nitrogen-limited regions (Fig. 3), while having less influence on the overall preformed nutrient pool and hence atmospheric carbon dioxide ${ }^{43,91}$.

Altered external nutrient inputs (Table 1) influence oceanic carbon storage through impacts on nutrient inventories ${ }^{46}$. Any potential impact on atmospheric carbon dioxide concentrations thus needs to be considered from this perspective. For example, the nitrogen inventory is thought to be stabilized by feedbacks that keep biological dinitrogen fixation in balance with the biological processes of fixed nitrogen loss ${ }^{4,27,34,42,44}$. Increasing anthropogenic atmospheric nitrogen inputs could directly increase the oceanic nitrogen inventory, driving a net drawdown of atmospheric carbon dioxide ${ }^{12,13}$. The associated increases in the ratio of external N:P inputs (Table 1) might, however, also act to reduce the current excess of phosphorus in oligotrophic waters (Fig. 3). Consequently, depending on the dominant environmental control(s) on dinitrogen fixation ${ }^{21,87}$ - particularly the extent to which iron or phosphorus is currently limiting $^{29,31,57,61,83}$ - the realized niche for diazotrophy might decrease, partially counteracting any increase in the fixed nitrogen inventory ${ }^{13}$. However, stoichiometric variability (Fig. 1) in phytoplankton $\mathrm{N}: \mathrm{P}$ uptake and/or remineralization ratios ${ }^{2,9,41,94}$ may further influence the niche for diazotrophs and the coupling of the nitrogen and phosphorus cycles both regionally ${ }^{94}$ and globally ${ }^{42}$.

The stoichiometries of biological matter production (Fig. 1) and cycling ${ }^{2}$ couple the marine carbon cycle to that of nutrient pools and fluxes $^{49}$. The relative constancy of the C:N ratio (Fig. 1) indicates that the total remineralized nitrogen pool could be considered the best measure of oceanic biological carbon storage (see Supplementary Information). Variability in the overall C:N ratio could thus have a significant influence on carbon storage ${ }^{49}$. More broadly, a better understanding of the environmental controls on variable elemental stoichiometries of different microbial groups ${ }^{2,25,42,94}$ would help to constrain the potential magnitude of any future carbon cycle responses.

\section{Future challenges}

The past two to three decades have seen the emergence of a firstorder description of large-scale patterns of phytoplankton nutrient limitation in the upper ocean (Fig. 3) and the biogeochemical consequences of this limitation. But clear gaps persist. Many regions remain under-sampled (Fig. 3), particularly with respect to the trace elements and the potential for interactive effects between multiple nutrients, including co-limitation ${ }^{7,8}$. Furthermore, our understanding of the extent to which important microbial groups such as diazotrophs and heterotrophs are nutrient-limited lags far behind that of (non-diazotrophic) phytoplankton. Recent research continues to highlight the magnitude, mechanisms and importance of stoichiometric variability for marine microbial activities at levels ranging from those of the microbial cell ${ }^{2,7,9,11,25}$ (Fig. 1a) through to the availability and supply of multiple nutrients at ocean-basin scales ${ }^{42-44,46,66}$ (Fig. 1b-d). But application of such knowledge to our understanding of existing patterns of nutrient limitation (Fig. 3), as well as past and potentially significant future change (Table 1 ), remains rudimentary. The details of how biological processes both influence and respond to the availability of nutrients remain debated even in the most well-studied case of nitrogen and phosphorus ${ }^{3,4,31,42,44,94}$, let alone for a wider suite of elements (Fig. 1).

Addressing these challenges will require an interdisciplinary approach. New analytical techniques, together with observational platforms such as gliders and floats fitted with nutrient sensors, and coordinated international sampling surveys such as GEOTRACES ${ }^{95}$ and the CLIVAR Repeat Hydrography Program, are all aiding better descriptions of the oceanic distributions of many more nutrients
(Fig. 1). Such data provide a basis for monitoring future change. From the biological perspective, even baseline information on the biogeographical distributions of key microbial groups, and associated metabolic rate processes, is lacking. Systematic evaluation of environmental controls, including nutrient limitation, on marine microbes lags even further behind. Applications of molecular tools should continue to yield insights, although linking such information to nutrient biogeochemistry in a quantitative way remains a challenge. Fuller exploitation of observations will also require better representation of trace metal cycling, flexible stoichiometry and multinutrient ecosystem interactions in numerical models. Only through synthesis of such diverse information will a more complete description emerge of the physical, chemical and biological interactions driving oceanic nutrient biogeochemistry.

Received 2 April 2012; accepted 8 February 2013; published online 31 March 2013

\section{References}

1. Frausto da Silva, J. J. R. \& Williams, R. J. P. The Biological Chemistry of the Elements: The Inorganic Chemistry of Life, 2nd edn (Oxford Univ. Press, 2001).

2. Sterner, R. W. \& Elser, J. J. Ecological Stoichiometry: The Biology of Elements from Molecules to the Biosphere (Princeton Univ. Press, 2002).

3. Redfield, A. C. in James Johnstone Memorial Volume, 176-192 (Liverpool Univ. Press, 1934).

4. Redfield, A. C., The biological control of chemical factors in the environment. Am. Sci. 46, 205-221 (1958).

5. de Baar, H. J. W., von Liebig's law of the minimum and plankton ecology (1899-1991). Prog. Oceanogr. 33, 347-386 (1994).

6. Morel, F. M. M., Milligan, A. J. \& Saito, M. A. Marine Bioinorganic Chemistry: The Role of Trace Metals in the Ocean Cycles of Major Nutrients. Treatise on Geochemistry Vol. 6, 113-143 (2003)

7. Arrigo, K. R. Marine microorganisms and global nutrient cycles. Nature 437, 349-355 (2005)

8. Saito, M. A., Goepfert, T. J. \& Ritt, J. T. Some thoughts on the concept of colimitation: Three definitions and the importance of bioavailability. Limnol. Oceanogr. 53, 276-290 (2008).

9. Geider, R. J. \& La Roche, J. Redfield revisited: variability of C:N:P in marine microalgae and its biochemical basis. Eur. J. Phycol. 37, 1-17 (2002).

10. Quigg, A. et al. The evolutionary inheritance of elemental stoichiometry in marine phytoplankton. Nature 425, 291-294 (2003).

11. Klausmeier, C. A., Litchman, E., Daufresne, T. \& Levin, S. A. Phytoplankton stoichiometry. Ecol. Res. 23, 479-485 (2008).

12. Duce, R. A. et al. Impacts of atmospheric anthropogenic nitrogen on the open ocean. Science 320, 893-897 (2008).

13. Krishnamurthy, A. et al. Impacts of increasing anthropogenic soluble iron and nitrogen deposition on ocean biogeochemistry. Glob. Biogeochem. Cycles 23, GB3016 (2009).

14. Falkowski, P. et al. The global carbon cycle: A test of our knowledge of Earth as a system. Science 290, 291-296 (2000).

15. Raven, J. A. Contributions of anoxygenic and oxygenic phototrophy and chemolithotrophy to carbon and oxygen fluxes in aquatic environments. Aquat. Microb. Ecol. 56, 177-192 (2009).

16. Eppley, R. W. \& Peterson, B. J. Particulate organic matter flux and planktonic new production in the deep ocean. Nature 282, 677-680 (1979).

17. Blackman, F. F. Optima and limiting factors. Ann. Bot. 19, 281-298 (1905).

18. Cullen, J. J. Hypotheses to explain high-nutrient conditions in the open sea. Limnol. Oceanogr. 36, 1578-1599 (1991).

19. von Liebig, J., Chemistry and its Application to Agriculture And Physiology. (Taylor and Walton, London, 1840).

20. Thingstad, T. F. et al. Nature of phosphorus limitation in the ultraoligotrophic eastern Mediterranean. Science 309, 1068-1071 (2005).

21. Boyd, P. W., Strzepek, R., Fu, F. X. \& Hutchins, D. A. Environmental control of open-ocean phytoplankton groups: Now and in the future. Limnol. Oceanogr. 55, 1353-1376 (2010).

22. Cavender-Bares, K. K., Mann, E. L., Chisholm, S. W., Ondrusek, M. E. \& Bidigare, R. R. Differential response of equatorial Pacific phytoplankton to iron fertilisation. Limnol. Oceanogr. 44, (1999).

23. Chisholm, S. W. in Primary Productivity and Biogeochemical Cycles in the Sea (eds Falkowski, P. G. \& Woodhead, A. D.) 213-237 (Plenum, 1992).

24. Raven, J. A. The twelfth Tansley lecture. Small is beautiful: The picophytoplankton. Funct. Ecol. 12, 503-513 (1998).

25. Van Mooy, B. A. S. et al. Phytoplankton in the ocean use non-phosphorus lipids in response to phosphorus scarcity. Nature 458, 69-72 (2009). 
26. Irigoien, X., Huisman, J. \& Harris, R. P. Global biodiversity patterns of marine phytoplankton and zooplankton. Nature 429, 863-867 (2004).

27. Tyrrell, T. The relative influences of nitrogen and phosphorus on oceanic primary production. Nature 400, 525-531 (1999).

28. Falkowski, P. G. Evolution of the nitrogen cycle and its influence on the biological sequestration of $\mathrm{CO}_{2}$ in the ocean. Nature 387, 272-275 (1997)

29. Mills, M. M., Ridame, C., Davey, M., La Roche, J. \& Geider, R. J. Iron and phosphorus co-limit nitrogen fixation in the eastern tropical North Atlantic. Nature 429, 292-294 (2004).

30. Moore, J. K. \& Doney, S. C. Iron availability limits the ocean nitrogen inventory stabilizing feedbacks between marine denitrification and nitrogen fixation. Glob. Biogeochem. Cycles 21, GB2001 (2007)

31. Moore, C. M. et al. Large-scale distribution of Atlantic nitrogen fixation controlled by iron availability. Nature Geosci. 2, 867-871 (2009).

32. Dupont, C. L., Butcher, A., Valas, R. E., Bourne, P. E. \& Caetano-Anolles, G. History of biological metal utilization inferred through phylogenomic analysis of protein structures. Proc. Natl Acad. Sci. USA 107, 10567-10572 (2010).

33. Anderson, L. A. \& Sarmiento, J. L. Redfield ratios of remineralization determined by nutrient data-analysis. Glob. Biogeochem. Cycles 8, 65-80 (1994).

34. Deutsch, C., Sarmiento, J. L., Sigman, D. M., Gruber, N. \& Dunne, J. P. Spatial coupling of nitrogen inputs and losses in the ocean. Nature 445, 163-167 (2007).

35. Ho, T. Y. et al. The elemental composition of some marine phytoplankton. J. Phycol. 39, 1145-1159 (2003).

36. Sunda, W. G. \& Huntsman, S. A. Cobalt and zinc interreplacement in marine phytoplankton: Biological and geochemical implications. Limnol. Oceanogr. 40, 1404-1417 (1995)

37. Sunda, W. G. \& Huntsman, S. A. Interrelated influence of iron, light and cell size on marine phytoplankton growth. Nature 390, 389-392 (1997).

38. Sunda, W. G. \& Huntsman, S. A. Control of Cd concentrations in a coastal diatom by interactions among free ionic $\mathrm{Cd}, \mathrm{Zn}$, and $\mathrm{Mn}$ in seawater. Environ. Sci. Technol. 32, 2961-2968 (1998).

39. Saito, M. A., Sigman, D. M. \& Morel, F. M. M. The bioinorganic chemistry of the ancient ocean: The co-evolution of cyanobacterial metal requirements and biogeochemical cycles at the Archean-Proterozoic boundary? Inorg. Chim. Acta 356, 308-318 (2003).

40. Grzymski, J. J. \& Dussaq, A. M. The significance of nitrogen cost minimization in proteomes of marine microorganisms. ISME J. 6, 71-80 (2012).

41. Wu, J., Sunda, W., Boyle, E. A. \& Karl, D. M. Phosphate depletion in the Western North Atlantic Ocean. Science 289, 759-762 (2000).

42. Lenton, T. M. \& Klausmeier, C. A. Biotic stoichiometric controls on the deep ocean N:P ratio. Biogeosciences 4, 353-367 (2007).

43. Sarmiento, J. L., Gruber, N., Brezinski, M. A. \& Dunne, J. P. High-latitude controls of thermocline nutrients and low latitude biological productivity. Nature 427, 56-60 (2004)

44. Deutsch, C. \& Weber, T. Nutrient ratios as a tracer and driver of ocean biogeochemistry. Annu. Rev. Mar. Sci. 4, 113-141 (2012).

45. Moore, J. K., Doney, S. C., Glover, D. M. \& Fung, I. Y. Iron cycling and nutrient-limitation patterns in surface waters of the World Ocean. Deep-Sea Res. II Top. Studies Oceanogr. 49, 463-507 (2002).

46. Krishnamurthy, A., Moore, J. K., Mahowald, N., Luo, C. \& Zender, C. S Impacts of atmospheric nutrient inputs on marine biogeochemistry. J. Geophys. Res. 115, G01006 (2010).

47. Moore, C. M. et al. Relative influence of nitrogen and phosphorus availability on phytoplankton physiology and productivity in the oligotrophic sub-tropical North Atlantic Ocean. Limnol. Oceanogr. 53, 291-305 (2008).

48. Tanaka, T. et al. Lack of P-limitation of phytoplankton and heterotrophic prokaryotes in surface waters of three anticyclonic eddies in the stratified Mediterranean Sea. Biogeosciences 8, 525-538 (2011).

49. Gruber, N. \& Galloway, J. N. An Earth-system perspective of the global nitrogen cycle. Nature 451, 293-296 (2008).

50. Flynn, K. J. Ecological modelling in a sea of variable stoichiometry: Dysfunctionality and the legacy of Redfield and Monod. Prog. Oceanogr. 84, 52-65 (2010).

51. Steinacher, M. et al. Projected 21st century decrease in marine productivity: A multi-model analysis. Biogeosciences 7, 979-1005 (2010).

52. Moutin, T. et al. Phosphate availability and the ultimate control of new nitrogen input by nitrogen fixation in the tropical Pacific Ocean. Biogeosciences 5, 95-109 (2008).

53. Martin, J. H. \& Fitzwater, S. E. Iron deficiency limits phytoplankton growth in the north-east Pacific subarctic. Nature 331, 341-343 (1988).

54. Boyd, P. W. et al. Mesoscale iron enrichment experiments 1993-2005: Synthesis and future directions. Science 315, 612-617 (2007).

55. Menzel, D. W. \& Ryther, J. H. Nutrients limiting the production of phytoplankton in the Sargasso Sea, with special reference to iron. Deep-Sea Res. 7, 276-281 (1961).
56. Graziano, L. M., Geider, R. J., Li, W. K. W. \& Olaizola, M. Nitrogen limitation of North Atlantic phytoplankton: Analysis of physiological condition in nutrient enrichment experiments. Aquat. Microb. Ecol. 11, 53-64 (1996).

57. Dyhrman, S. T., Webb, E. A., Anderson, D. M., Moffett, J. W. \& Waterbury, J. B. Cell-specific detection of phosphorus stress in Trichodesmium from the western north Atlantic. Limnol. Oceanogr. 47, 1832-1836 (2002).

58. Lomas, M. W., Swain, A., Shelton, R. \& Ammerman, J. W. Taxonomic variability of phosphorus stress in Sargasso Sea phytoplankton. Limnol. Oceanogr. 49, 2303-2310 (2004)

59. Zohary, T. et al. P-limited bacteria but $\mathrm{N}$ and $\mathrm{P}$ co-limited phytoplankton in the Eastern Mediterranean: A microcosm experiment. Deep-Sea Res. II 52, 3011-3023 (2005)

60. La Roche, J., Geider, R. J., Graziano, L. M., Murray, H. \& Lewis, K. Induction of specific proteins in eukaryotic algae grown under iron-, phosphorus-, or nitrogen-deficient conditions. J. Phycol. 29, 767-777 (1993).

61. Chappell, P. D., Moffett, J. W., Hynes, A. M. \& Webb, E. A. Molecular evidence of iron limitation and availability in the global diazotroph Trichodesmium. ISME J. 6, 1728-1739 (2012).

62. Marchetti, A. et al. Comparative metatranscriptomics identifies molecular bases for the physiological responses of phytoplankton to varying iron availability. Proc. Natl Acad. Sci. USA 109, E317-E325 (2012).

63. Sigman, D. M., Hain, M. P. \& Haug, G. H. The polar ocean and glacial cycles in atmospheric $\mathrm{CO}_{2}$ concentration. Nature 466, 47-55 (2010).

64. Martinez-Garcia, A. et al. Southern Ocean dust-climate coupling over the past four million years. Nature 476, 312-315 (2011)

65. Ren, H. et al. Foraminiferal isotope evidence of reduced nitrogen fixation in the ice age Atlantic Ocean. Science 323, 244-248 (2009)

66. Noble, A. E. et al. Basin-scale inputs of cobalt, iron, and manganese from the Benguela-Angola front to the South Atlantic Ocean. Limnol. Oceanogr. 57, 989-1010 (2012).

67. Shi, D. L., Xu, Y., Hopkinson, B. M. \& Morel, F. M. M. Effect of ocean acidification on iron availability to marine phytoplankton. Science 327, 676-679 (2010).

68. Beman, J. M. et al. Global declines in oceanic nitrification rates as a consequence of ocean acidification. Proc. Natl Acad. Sci. USA 108, 208-213 (2011).

69. Sunda, W. G. Iron and the carbon pump. Science 327, 654-655 (2010).

70. Sarmiento, J. L., Hughes, T. M. C., Stouffer, R. J. \& Manabe, S. Simulated response of the ocean carbon cycle to anthropogenic climate warming. Nature 393, 245-249 (1998)

71. Sarmiento, J. L. et al. Response of ocean ecosystems to climate warming. Glob. Biogeochem. Cycles 18, GB3003 (2004).

72. Polovina, J. J., Howell, E. A. \& Abecassis, M. Ocean's least productive waters are expanding. Geophys. Res. Lett. 35, L03618 (2008)

73. Saba, V. S. et al. Challenges of modeling depth-integrated marine primary productivity over multiple decades: A case study at BATS and HOT. Glob. Biogeochem. Cycles 24, GB3020 (2010).

74. Henson, S. A. et al. Detection of anthropogenic climate change in satellite records of ocean chlorophyll and productivity. Biogeosciences 7, 621-640 (2010)

75. Stramma, L., Johnson, G. C., Sprintall, J. \& Mohrholz, V. Expanding oxygenminimum zones in the tropical oceans. Science 320, 655-658 (2008)

76. Godfray, H. C. J. et al. Food security: The challenge of feeding 9 billion people. Science 327, 812-818 (2010).

77. Mahowald, N. et al. Global distribution of atmospheric phosphorus sources, concentrations and deposition rates, and anthropogenic impacts. Glob. Biogeochem. Cycles 22, GB4026 (2008).

78. Mahowald, N. M. et al. Observed 20th century desert dust variability: Impact on climate and biogeochemistry. Atmos. Chem. Phys. 10, 10875-10893 (2010)

79. Seitzinger, S. P. et al. Global river nutrient export: A scenario analysis of past and future trends. Glob. Biogeochem. Cycles 24, GB0A08 (2010).

80. Cordell, D., Drangert, J. O. \& White, S. The story of phosphorus: Global food security and food for thought. Glob. Environ. Change Hum. Policy Dimens. 19, 292-305 (2009).

81. Raiswell, R. \& Canfield, D. E. The iron biogeochemical cycle past and present geochemical perspectives. Geochem. Persp. 1, 1-220 (2012).

82. Jickells, T. D. et al. Global iron connections between desert dust, ocean biogeochemistry, and climate. Science 308, 67-71 (2005).

83. Monteiro, F. M., Dutkiewicz, S. \& Follows, M. J. Biogeographical controls on the marine nitrogen fixers. Glob. Biogeochem. Cycles 25, GB2003 (2011)

84. Diaz, R. J. \& Rosenberg, R. Spreading dead zones and consequences for marine ecosystems. Science 321, 926-929 (2008)

85. Levitan, O. et al. Elevated $\mathrm{CO}_{2}$ enhances nitrogen fixation and growth in the marine cyanobacterium Trichodesmium. Glob. Change Biol. 13, 531-538 (2007).

86. Eppley, R. W. Temperature and phytoplankton growth in the sea. Fishery Bull. 70, 1063-1085 (1972) 
87. Shi, D., Kranz, S. A., Kim, J-M. \& Morel, F. M. M. Ocean acidification slows nitrogen fixation and growth in the dominant diazotroph Trichodesmium under low-iron conditions. Proc. Natl Acad. Sci. USA 109, E3094-3100 (2012).

88. Taucher, J. \& Oschlies, A. Can we predict the direction of marine primary production change under global warming? Geophys. Res. Lett. 38, 6 (2011).

89. Breitbarth, E., Oschlies, A. \& LaRoche, J. Physiological constraints on the global distribution of Trichodesmium - effect of temperature on diazotrophy. Biogeosciences 4, 53-61 (2007).

90. Marinov, I. et al. Impact of oceanic circulation on biological carbon storage in the ocean and atmospheric $\mathrm{pCO}_{2}$. Glob. Biogeochem. Cycles 22, GB3007 (2008).

91. Marinov, I., Gnanadesikan, A., Toggweiler, J. R. \& Sarmiento, J. L. The Southern Ocean biogeochemical divide. Nature 441, 964-967 (2006).

92. Ito, T. \& Follows, M. J. Preformed phosphate, soft tissue pump and atmospheric $\mathrm{CO}_{2}$. J. Mar. Res. 63, 813-839 (2005).

93. Sarmiento, J. L. \& Toggweiler, J. R. A new model for the role of the oceans in determining atmospheric $p \mathrm{CO}_{2}$. Nature 308, 621-624 (1984).

94. Mills, M. M. \& Arrigo, K. R. Magnitude of oceanic nitrogen fixation influenced by the nutrient uptake ratio of phytoplankton. Nature Geosci. 3, 412-416 (2010).

95. Henderson, G. M. et al. GEOTRACES-An international study of the global marine biogeochemical cycles of trace elements and their isotopes. Chem. Erde Geochem. 67, 85-131 (2007).

96. Raiswell, R. et al. Contributions from glacially derived sediment to the global iron (oxyhydr)oxide cycle: Implications for iron delivery to the oceans. Geochim. Cosmochim. Acta 70, 2765-2780 (2006).

97. Wynn, P. M., Hodson, A. J., Heaton, T. H. E. \& Chenery, S. R. Nitrate production beneath a high arctic glacier, Svalbard. Chem. Geol. 244, 88-102 (2007).
98. Wallmann, K. Phosphorus imbalance in the global ocean? Glob. Biogeochem Cycles 24, GB4030 (2010).

99. Cullen, J. J., Yang, X. \& MacIntyre, H. L. in Primary Productivity and Biogeochemical Cycles in the Sea (eds Falkowski, P. G. \& Woodhead, A.) 69-88 (Plenum, 1992).

100. Thingstad, T. F., Ovreas, L., Egge, J. K., Lovdal, T. \& Heldal, M. Use of nonlimiting substrates to increase size; a generic strategy to simultaneously optimize uptake and minimize predation in pelagic osmotrophs? Ecol. Lett. 8, 675-682 (2005).

\section{Acknowledgements}

This review results from the activities of the International Geosphere-Biosphere Programme (IGBP) Fast Track Initiative on Upper Ocean Nutrient Limitation and in particular a workshop hosted at the National Oceanography Centre, Southampton, UK. Financial support for the workshop was provided by IGBP, US Ocean Carbon and Biogeochemistry, the Scientific Committee on Oceanic Research (SCOR) and EUCOST-735.

\section{Additional information}

Supplementary information accompanies this paper on www.nature.com/ naturegeoscience. Reprints and permissions information is available online at www.nature.com/reprints. Correspondence and requests for materials should be addressed to C.M.M. or M.M.M.

\section{Competing financial interests}

The authors declare no competing financial interests.

C. M. Moore ${ }^{1 \star}$, M. M. Mills ${ }^{2 \star}$, K. R. Arrigo ${ }^{2}$, I. Berman-Frank ${ }^{3}$, L. Boppp ${ }^{4}$ P. W. Boyd ${ }^{5,6}$, E. D. Galbraith ${ }^{7}$ R. J. Geider ${ }^{8}$, C. Guieu' ${ }^{9}$, S. L. Jaccard ${ }^{10}$, T. D. Jickells ${ }^{11}$, J. La Roche ${ }^{12,13}$, T. M. Lenton ${ }^{14}$, N. M. Mahowald ${ }^{15}$, E. Marañón ${ }^{16}$, I. Marinovv', J. K. Moore ${ }^{18}$, T. Nakatsuka' ${ }^{19}$, A. Oschlies ${ }^{12}$, M. A. Saito ${ }^{20}$, T. F. Thingstad ${ }^{21}$, A. Tsuda ${ }^{22}$ and O. Ulloa ${ }^{23}$

'Ocean and Earth Science, University of Southampton, National Oceanography Centre, Southampton, European Way, Southampton SO14 3ZH, UK. ${ }^{2}$ Department of Environmental Earth System Science, Stanford University, Stanford, California 94305, USA. ${ }^{3}$ Mina and Everard Goodman Faculty of Life Sciences, Bar Ilan University, Ramat Gan, 5290002, Israel. " 4 Laboratoire des Sciences du Climat et de I'Environnement, UVSQ, IPSL, CEA, CNRS, Gif-sur-Yvette, France. ${ }^{5}$ National Institute of Water and Atmosphere Centre of Chemical and Physical Oceanography, Department of Chemistry, University of Otago, Dunedin, New Zealand. ${ }^{6}$ Institute for Marine and Antarctic Studies, University of Tasmania, Private Bag 129, Hobart, TAS 7001, Australia. ${ }^{7}$ Department of Earth and Planetary Science, McGill University, Montreal, QC, Canada. ${ }^{8}$ School of Biological Sciences, University of Essex, Colchester CO4 3SQ, UK. 'Laboratoire d'Océanographie de Villefranche/Mer, CNRS-INSU UMR7093, Université Pierre et Marie Curie-Paris 6, F-06230, Villefranche-sur-Mer, France. ${ }^{10}$ Geological Institute, Department of Earth Sciences, ETH Zurich, CH-8092 Zurich, Switzerland. "'Laboratory for Global Marine and Atmospheric Chemistry, School of Environmental Sciences, University of East Anglia, Norwich, UK. ${ }^{12}$ Helmholtz-Zentrum für Ozeanforschung Kiel (GEOMAR), D-24105 Kiel, Germany. ${ }^{13}$ Department of Biology, Dalhousie University, Halifax, Nova Scotia, Canada. ${ }^{14}$ College of Life and Environmental Sciences, University of Exeter, Hatherly Laboratories, Prince of Wales Road, Exeter EX4 4PS, UK. ${ }^{15}$ Department of Earth and Atmospheric Sciences, Cornell University, Ithaca, New York 14850, USA. ${ }^{16}$ Departamento de Ecología y Biología Animal, Universidad de Vigo, Campus Lagoas-Marcosende, 36310 Vigo, Spain. ${ }^{17}$ Department of Earth and Environmental Science, University of Pennsylvania, 240 South 33rd Street, Philadelphia, Pennsylvania 19104, USA. ${ }^{18}$ Earth System Science, University of California, Irvine, California 92697, USA. ${ }^{19} \mathrm{Graduate}$ School of Environmental Studies, Nagoya University, Nagoya 464-8601, Japan. ${ }^{20}$ Marine Chemistry and Geochemistry Department, Woods Hole Oceanographic Institution, Woods Hole, Massachusetts 02543, USA. ${ }^{21}$ Department of Biology, University of Bergen, 5020 Bergen, Norway. ${ }^{22}$ Atmosphere and Ocean Research Institute, University of Tokyo, Kashiwa, Chiba 277-8564, Japan. ${ }^{23}$ Departamento de Oceanografía, Universidad de Concepción, Casilla $160-C, 4070386$ Concepción, Chile. *e-mail: cmm297@noc.soton.ac.uk; mmmills@stanford.edu 